\title{
GESTÃO DE FONTES DE MATÉRIA-PRIMA LÍTICA PELOS CONSTRUTORES DE CERRITOS NO SUL DO BRASIL: UM ESTUDO DE CASO
}

ANDERSON MARQUES GARCIA ${ }^{1}$

UFSM

RAFAEL GUEDES MILHEIRA ${ }^{2}$

UFPel

\begin{abstract}
RESUMO: Este artigo investiga o tema da gestão de matérias-primas líticas pelos grupos construtores de Cerritos da Laguna dos Patos, no sul do Brasil, especificamente pelos habitantes do sítio arqueológico "PT-02 - Cerrito da Sotéia", localizado na Ilha da Feitoria, município de Pelotas-RS. Esse sítio arqueológico foi datado pelo método radio carbônico AMSStandard entre $1010 \pm 40$ A.P. e $990 \pm 40$ A.P. Foram analisados os mapas geológicos do Estado do Rio Grande do Sul e do município de Pelotas em complementação às saídas de campo, a fim de mapear áreas potenciais de ocorrência de matérias-primas. Foi usada também a microscopia eletrônica de varredura (MEV) como método auxiliar na identificação de matéria-prima lítica.
\end{abstract}

PALAVRAS-CHAVE: Cerritos; Gestão de matéria-prima; Zonas de atividades econômicas.

ABSTRACT: This paper investigates the issue of lithic raw materials management by moundbuilders of Laguna dos Patos, southern Brazil, specifically by the inhabitants of the site "PT-02 - the Sotéia Cerrito", located in the Feitoria Island, the city of Pelotas, RS. This site was dated by radiocarbon method AMS-Standard between $1010 \pm 40 \mathrm{BP}$ and $990 \pm 40 \mathrm{AP}$. There were analyzed the geological maps of the State of Rio Grande do Sul and the municipality of Pelotas as a complement of fieldwork in order to map potential areas where is the occurrence of raw materials. It was also used the Scanning Electron Microscope (SEM) as an auxiliary method in the identification of lithic raw materials.

KEYWORDS: Cerritos; Raw material management; Zones of economic activity.

\footnotetext{
${ }^{1}$ Mestre em Patrimônio Cultural pela Universidade Federal de Santa Maria. Pesquisador associado ao LEPAARQ/UFPel e ao LEPA/UFSM (Rua Floriano Peixoto, N. ${ }^{\circ}$ 1184, Centro, CEP: 97105-372, Santa Maria-RS - Brasil). E-mail: andersonmarquesgarcia@gmail.com .

2 Professor do Bacharelado em Antropologia/Arqueologia e do Programa de Pós-graduação em Antropologia da Universidade Federal de Pelotas. Coordenador do LEPAARQ/UFPel (Instituto de Ciências Humanas, Rua Cel. Alberto Rosa, N. ${ }^{\circ}$ 154, Bairro Porto, CEP: 96010-770, Pelotas-RS Brasil).E-mail: milheirarafael@gmail.com.
}

Espaço Ameríndio, Porto Alegre, v. 7, n. 1, p. 10-36, jan./jun. 2013. 
ANDERSON M. GARCIA e RAFAEL G. MILHEIRA - Gestão de fontes de matéria-prima...

\section{Introdução}

No presente estudo tem-se por objetivo o desenvolvimento do tema referente ao aprovisionamento e gestão de matérias-primas líticas utilizadas pelos grupos construtores de Cerritos do Sudoeste da Laguna dos Patos $^{3}$. O sítio arqueológico que tomaremos como base para o estudo é o "PT-02- Cerrito da Sotéia", localizado no município de Pelotas-RS, sobre o qual já foram desenvolvidas diversas pesquisas que permitem um entendimento mais amplo de suas características: processos de formação do sítio (LOUREIRO, 2008); indústria cerâmica (BELLETTI, 2010); vestígios arqueofaunísticos (ULGUIM, 2010) e indústria lítica (GARCIA, 2010). Apresentaremos o mapeamento e o georreferenciamento das fontes de matéria-prima mais próximas à área de ocorrência do Cerrito da Sotéia para entender, do ponto de vista sistêmico, a relação de distância entre a área de ocupação e possíveis áreas de aprovisionamento dos recursos líticos. Além do mapeamento de algumas fontes em campo e do uso dos mapas geológicos do Estado do Rio Grande do Sul e do município de Pelotas, realizamos também uma análise através do método de microscopia eletrônica de varredura (MEV) como forma de auxiliar na identificação de uma matéria-prima específica usada pelos cerriteiros: o andesito.

Os Cerritos podem ser definidos como estruturas arqueológicas monticulares de formação antrópica construídas predominantemente com terra, fazendo parte de sua composição diferentes vestígios de cultura material, como, por exemplo: arqueofauna, instrumentos líticos e cerâmicos, estruturas de fogueiras e sepultamentos humanos. Os sítios arqueológicos com Cerritos ${ }^{4}$ se encontram no Sul da América do Sul, distribuídos nas porções Leste e Norte do Uruguai, Sul do Brasil (Rio Grande do Sul) e na porção Nordeste da Argentina. Quanto a estudos relativos à função destas estruturas, existem diversas interpretações

\footnotetext{
${ }^{3}$ Agradecemos aos colegas Carlos Roberto Appoloni e Aluisio Gomes Alves, cujas contribuições foram essenciais para o desenvolvimento das discussões apresentadas.

${ }^{4}$ Tratamos aqui de sítios com Cerritos, já que, desde, pelo menos, os anos 1980, os cerritos são entendidos como elementos componentes do espaço da aldeia e não como o sítio arqueológico em si. Ver discussão neste sentido em López Mazz e Gianotti (1998).
}

Espaço Ameríndio, Porto Alegre, v. 7, n. 1, p. 10-36, jan./jun. 2013. 
ANDERSON M. GARCIA e RAFAEL G. MILHEIRA - Gestão de fontes de matéria-prima...

para áreas específicas deste fenômeno de larga abrangência espacial. Sintetizando a literatura especializada, pode-se dizer que os Cerritos são pensados como áreas de sepultamento, acampamentos de caça e pesca, demarcadores territoriais, locais de descarte de refugo, praças centrais das aldeias, plataformas de terra erguidas para habitação em áreas alagadiças. São interpretados também como monumentos que remontam à memória social e à identidade dos grupos caçadorescoletores que habitaram o ambiente pampiano, sendo indicadores de territorialidade e complexidade social (NAUE, 1973; SCHMITZ, 1976; RÜTHSCHILLING, 1987 e 1989; HILBERT, 1991; BASILE-BECKER, 1992; PINTOS BLANCO, 1999; LÓPEZ MAZZ, 2000; IRIARTE, 2000; VILLAGRÁN, 2005; BONOMO, POLITIS e GIANOTTI, 2011 ).

No que se refere à continuidade histórica, os Cerritos de uma forma geral são interpretados como construções resultantes da ocupação dos Minuano ${ }^{5}$, grupo ameríndio que habitou a região que coincide com a ampla área de ocorrência dos Cerritos. Os relatos sobre estas populações ameríndias são bastante frequentes nos documentos de cronistas e viajantes europeus que exploraram a referida região a partir do século XVII, o que enriquece as interpretações arqueológicas sobre os Cerritos nas suas diferentes áreas de ocorrência (BASILEBECKER, 1992 e 2002; LÓPEZ MAZZ e BRACCO, 2010).

Os Cerritos alcançam um horizonte cronológico de 4.500 A.P. em sítios arqueológicos localizados no Uruguai, onde atingem dimensões de 100 metros de diâmetro por até 7 metros de altura (LÓPEZ MAZZ, 2000; IRIARTE, 2000; VILLAGRÁN, 2005; LÓPEZ MAZZ e BRACCO, 2010). Porém, especificamente na região meridional da Laguna dos Patos, os Cerritos ocorrem na paisagem de forma menos imponente, alcançando dimensões menores que giram em torno de 70 metros de diâmetro e 1,2 metros de altura, com uma profundidade temporal entre $2.435 \pm 85$ e $200 \pm 80$ A. P (datas radiocarbônicas) (SCHMITZ, 1976; SCHMITZ, NAUE e BASILE-BECKER, 1992). Segundo Schmitz (1976), devido a

\footnotetext{
${ }^{5}$ López Mazz \& Bracco (2010) sugerem que os Cerritos possam estar relacionados com os Minuano e não com os Charrua e Minuano, como tem sido argumentado nas últimas décadas. Esta hipótese se dá em função da sobreposição da ocorrência dos Cerritos e das áreas historicamente conhecidas, onde os grupos foram encontrados pelos viajantes europeus. Os lugares de Cerritos coincidem em muito com o território Minuano encontrado pelos conquistadores, já o território Charrua original diferiria bastante dos lugares de ocorrência dos Cerritos. Contudo, esta é uma questão ainda não resolvida arqueologicamente e é aqui apresentada com fim de enriquecer esta discussão.
}

Espaço Ameríndio, Porto Alegre, v. 7, n. 1, p. 10-36, jan./jun. 2013. 
ANDERSON M. GARCIA e RAFAEL G. MILHEIRA - Gestão de fontes de matéria-prima...

grande frequência de espécies de fauna lacustre que compõe o registro arqueológico, os Cerritos da porção meridional da laguna dos Patos podem ser interpretados como acampamentos de pesca. Seriam espaços ocupados sazonalmente dentro de um sistema de mobilidade dos grupos cerriteiros que se articularia entre o interior (outono e inverno) e litoral (primavera e verão). Essa interpretação decorre do fato de que

(...) os peixes presentes [no registro arqueológico] são da primavera e do verão; ausentes os do outono e inverno. Os crustáceos presentes são todos do período quente, primavera e verão. Os coquinhos de jerivá são do começo do verão de modo que, pela presença dos peixes, crustáceos e coquinhos, temos provas de que o assentamento é ocupado na primavera e começo do verão e não ocupado durante o período de outono e inverno (SCHMITZ, 1976, p. 215).

\section{O sítio PT-02-Cerrito da Sotéia: localização, composição e cultura material}

O sítio "PT-02-Cerrito da Sotéia" situa-se na llha da Feitoria (coordenadas em UTM SAD 69 [22J] 403511/6500979) no município de Pelotas, Estado do Rio Grande do Sul (figura 01). A ilha da Feitoria, embora tenha esse nome popular, é na verdade um "esporão arenoso" típico da porção meridional desta laguna, formado por areias sedimentares provenientes principalmente da erosão do Escudo Sul-riograndense (Serra do Sudeste). Trata-se de uma área composta por sedimentos síltico-argilosos de planície de inundação, terraços e depósitos de calha de rede fluvial e subatual. São depósitos inconsolidados compostos por areias finas, médias e quartzosas de tonalidade esbranquiçada de caráter fluviolacustre, oriundos do assoreamento de lagoas costeiras (RADAM BRASIL, 1986). Com esta formação de areias quartzosas, a Ilha da Feitoria tem uma cobertura vegetal de matas pioneiras e áreas de reflorestamento recente. Além disso, ocorrem áreas alagadiças (banhados) e matas galerias, estas, registro das transgressões e regressões das águas da Laguna sobre o terreno da Ilha, cujas alturas oscilam em torno de 3 metros com relação ao nível do mar. Na sua margem oeste se localiza o sangradouro da 
Lagoa Pequena, onde procriam e desovam várias espécies de peixes e crustáceos (ROSA, 1985).
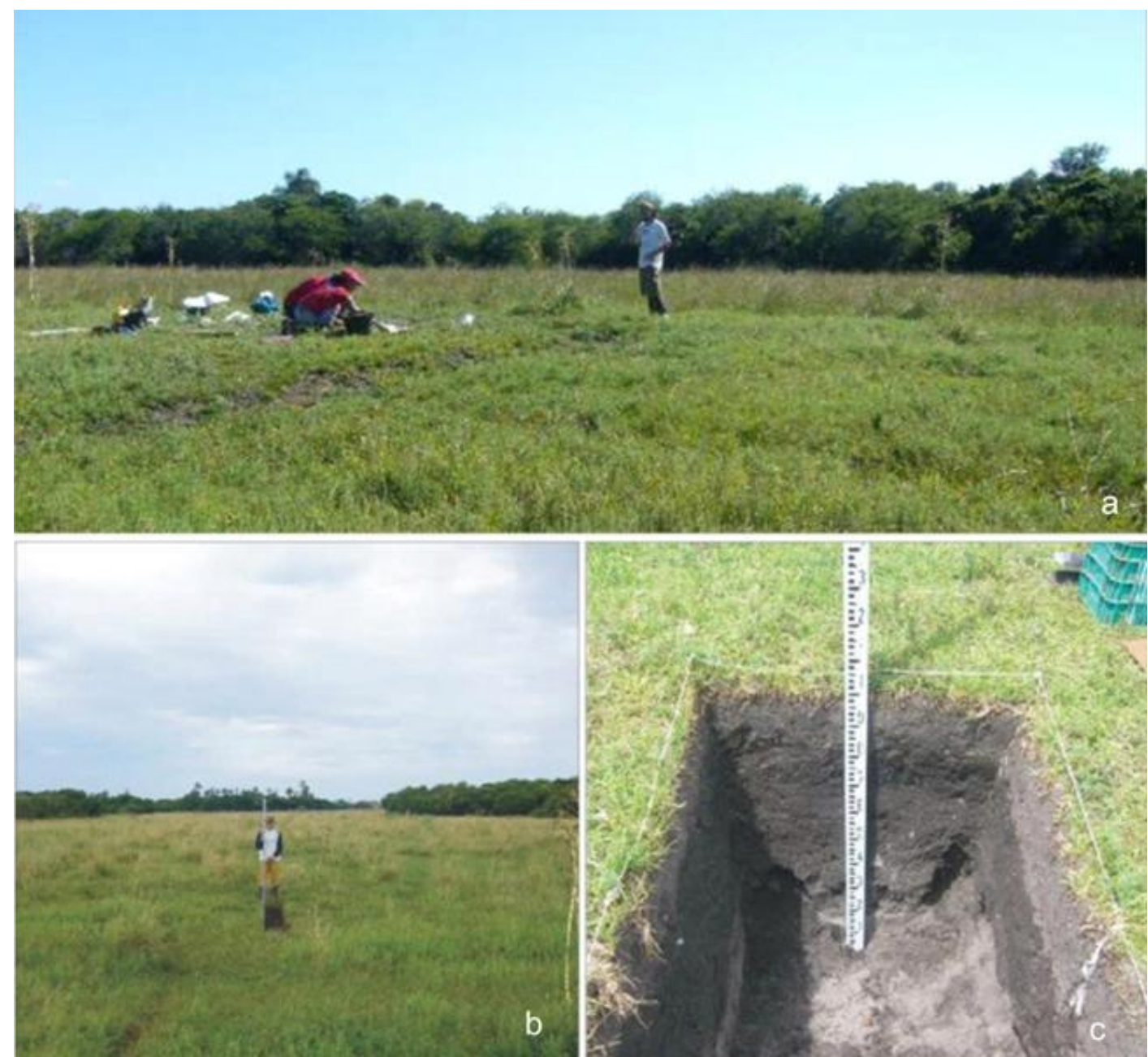

Figura 01: Cerrito da Sótéia na Ilha da Feitoria. (a) Vista geral do Cerrito no sentido leste-oeste, em que se nota a elevação do montículo em campo aberto; (b) vista geral do Cerrito no sentido norte-sul durante realização de medições topográficas e escavação de trincheira; (c) escavação de sondagem, em que se pode notar a camada basal com coloração clara, camada arqueológica (intermediária) com grande concentração de materiais arqueológicos com coloração cinza escuro/preta e camada superior de formação húmica com coloração cinza claro (foto: acervo do LEPAARQ/UFPel).

A ilha da Feitoria encontra-se em um terreno sedimentar pertencente à província geomorfológica denominada Planície Costeira, datada em torno de 400.000 A.P. (VILLWOCK e TOMAZELLI, 1995). Esta 
ANDERSON M. GARCIA e RAFAEL G. MILHEIRA - Gestão de fontes de matéria-prima...

província tem seu processo de formação ligado a um evento de deposição de sedimentos conhecido como Sistema Laguna-Barreira, que é marcado por quatro barreiras de sedimentos transportados durante as últimas transgressões e regressões marinhas ocorridas no Período Quaternário.

O Cerrito da Sotéia está inserido sobre uma área composta de depósitos de praia e cristais lagunares, bem como por depósitos da barreira da planície lagunar IV (MARTH, KOESTER e ARNDT, 2008). Essa barreira é a mais recente do sistema, localizando-se próxima à atual costa marítima. Tal sequência cronológica pode ser percebida através das planícies de inundação de cada uma das barreiras e por similaridades físicas e químicas existentes na composição dos sedimentos. Devido às características geomorfológicas citadas, estas áreas são sujeitas a constantes inundações, gerando ambientes úmidos e alagadiços que foram comumente escolhidos para o assentamento das populações construtoras de Cerritos.

Tendo sido identificado no ano de 2005, o Cerrito da Sotéia foi foco de três intervenções arqueológicas até o ano de 2007. Foi realizada uma topografia refinada do sítio e escavações, através das quais se pôde constatar tratar-se de um montículo com formato elipsoidal com altura de $80 \mathrm{~cm}$; eixo norte de $20 \mathrm{~m}$ e eixo leste de $15 \mathrm{~m}$. Realizou-se a escavação de cinco sondagens de $1 \times 0,5 \mathrm{~m}$ no topo e entorno do montículo e 18 quadras de $1 \mathrm{~m}^{2}$, formando duas trincheiras entrecruzadas no sentido Leste-Oeste e Norte-Sul. Estas intervenções permitiram observar a composição estratigráfica do montículo desde o centro até a margem e do topo à base do mesmo. A estratigrafia do Cerrito se mostrou bastante homogênea, sendo composta por três camadas bem definidas de sedimento arenoso com coloração do cinza claro ao cinza escuro ${ }^{6}$, respectivamente, havendo também, algumas lentes estéreis cuja formação e função ainda são desconhecidas. A quadra 40.30, localizada no topo do Cerrito, foi datada com amostras de otólitos através do método de AMS-Standard, obtendo-se as datas

\footnotetext{
${ }^{6}$ Num primeiro momento a diferença de coloração foi tratada como evidência de momentos distintos de construção do montículo (Cf. LOUREIRO, 2008), porém, novos estudos serão realizados para compreender a origem destes sedimentos e averiguar se a diferença de coloração não resulta apenas de umidade mais densa na base, gerando um sedimento mais escuro.
}

Espaço Ameríndio, Porto Alegre, v. 7, n. 1, p. 10-36, jan./jun. 2013. 
convencionais de $1400 \pm 40$ A.P. para a base do Cerrito e de $1360 \pm 40$ A.P. para o topo ${ }^{7}$ (LOUREIRO, 2008).

No que se refere aos aspectos funcionais, o sítio "PT-02" pode ser interpretado como um acampamento de pesca lacustre, visto que é abundante a presença de vestígios arqueofaunísticos oriundos da laguna dos Patos (ULGUIM, 2010), reforçando, neste caso, a hipótese funcional apresentada por Schmitz (1976) para os Cerritos da laguna dos Patos. Porém, este mesmo espaço deve ter sido utilizado também como área de descarte de materiais de uma pequena aldeia, pois, conforme a topografia demonstrou, no entorno do montículo central, haveria pequenas elevações (microrrelevos) indicativas das áreas de habitação (LOUREIRO, 2008). Neste sentido, o montículo seria um espaço multifuncional utilizado tanto como área de pesca e processamento de recursos lacustres, quanto como espaço de moradia ocupado e utilizado por um período que pode chegar a aproximadamente cem anos.

O Cerrito da Sotéia, embora se encontre isolado na ilha da Feitoria, faz parte de um grande complexo de Cerritos localizados nas margens da laguna dos Patos. Neste contexto regional de ocupação, além do sítio Cerrito da Sotéia, foram mapeados até o momento outros 23 Cerritos localizados na região do município de Pelotas ${ }^{8}$ (figura 02) (LOUREIRO, 2008; MILHEIRA, 2008; MÜHLEN et al, 2011). Estes, somados aos demais Cerritos identificados na porção meridional da laguna dos Patos, desde os anos 1960, ultrapassam um total de uma centena de sítios; sugerindo, portanto, um contexto regional de ocupação de longa duração bastante denso e complexo a ser investigado, cuja história ultrapassa um horizonte cronológico de mais de 2.000 anos. Ver estudos sobre os demais contextos em Schmitz (1976), Rüthschilling (1989), Schmitz, Naue e Basile-Becker (1992); Copé (1992) e Pereira (2008).

\footnotetext{
${ }^{7}$ Estas datas calibradas com um sigma possibilitam uma interpretação de um intervalo temporal entre topo e base girando entre momentos contemporâneos até o máximo 132 anos. As datas calibradas são: base de 990 à 901 A.P. (995 à 1092 d.C.) e topo de 955 à 858 A.P. (960 à 1049 d.C.).

${ }^{8}$ Os demais Cerritos encontrados na região do município de Pelotas distam entre 20 e $30 \mathrm{~km}$ a partir do Cerrito da Sotéia, havendo uma concentração no banhado do Valverde e nas margens da Lagoa do Fragata.
}

Espaço Ameríndio, Porto Alegre, v. 7, n. 1, p. 10-36, jan./jun. 2013. 
ANDERSON M. GARCIA e RAFAEL G. MILHEIRA - Gestão de fontes de matéria-prima...
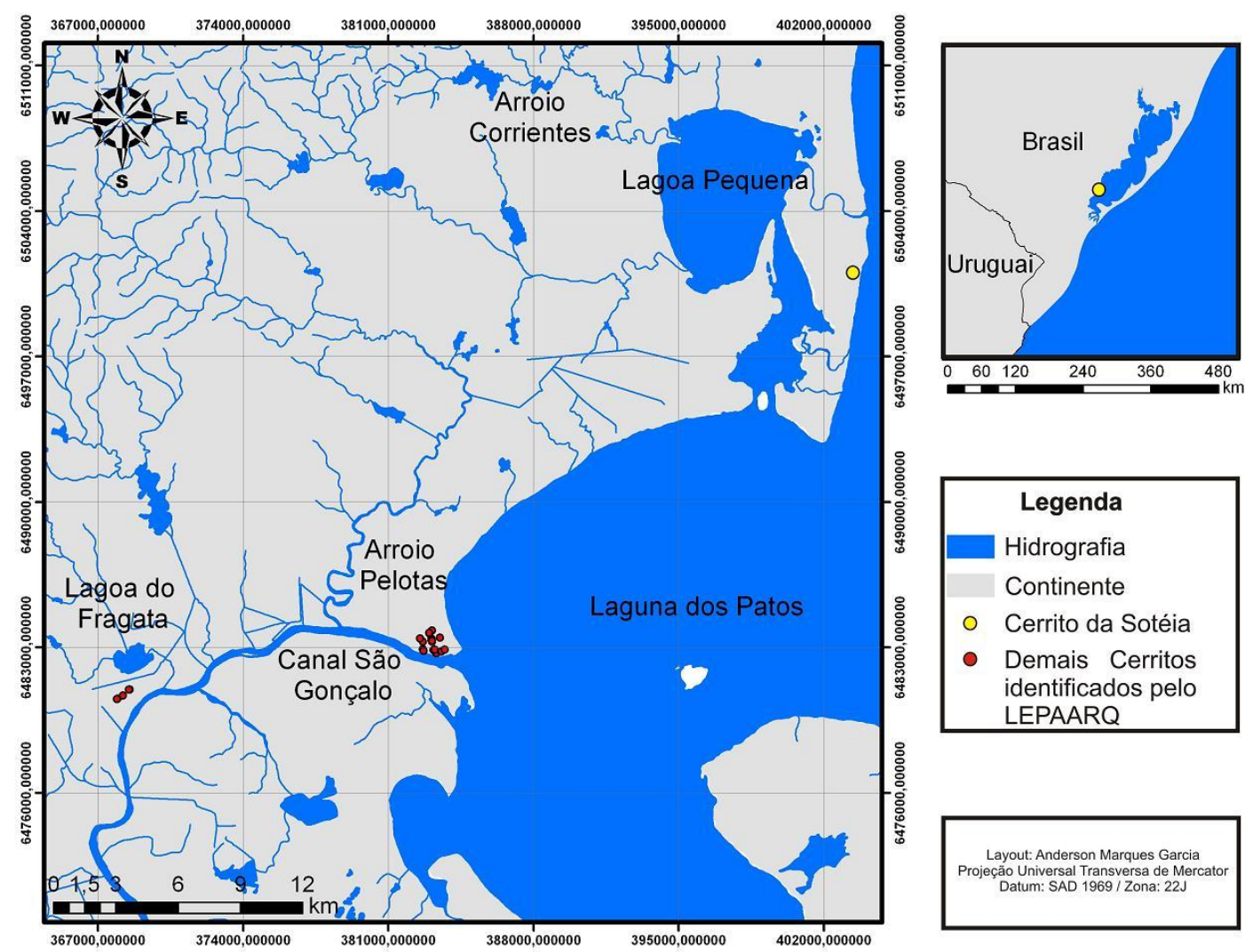

Figura 02: Localização do Cerrito da Sotéia, na Ilha da Feitoria. Nas proximidades do Canal São Gonçalo vê-se duas concentrações de Cerritos, uma nas margens da Lagoa do Fragata e a outra junto ao Banhado do Valverde.

Quanto aos estudos da cultura material do Cerrito da Sotéia, a análise realizada sobre os vestígios arqueofaunísticos indica que os elementos ósseos oriundos de peixes $(68,05 \%)$ predominam na amostra, sendo seguido de malacostraca (18\%), bivalves $(11,51 \%)$, mamíferos $(1,22 \%)$, aves $(0,69 \%)$ e gastrópodes $(0,50 \%)$. Além de sugerir que a base da dieta alimentar dos cerriteiros seria composta primeiramente por peixes de espécies como miraguaia, corvina e bagres; muitos ossos apresentaram marcas de alteração térmica (carbonização e calcinamento), indicando que o processamento dos alimentos se daria in situ, através de técnicas de cozimento (com uso de vasilhas cerâmicas) e/ou assado. As principais espécies de peixes identificadas foram a corvina, a miraguaia e o bagre, os quais são peixes típicos de primavera e verão, e que desovam nas águas da laguna dos 
ANDERSON M. GARCIA e RAFAEL G. MILHEIRA - Gestão de fontes de matéria-prima...

Patos no período de salinização, assemelhando-se aos padrões dos demais sítios estudados na região.

A indústria cerâmica é composta por aproximadamente 1800 fragmentos que remontam a vasilhas típicas da denominada tradição Vieira, descritas como "cerâmicas funcionais", ou seja: trata-se de potes com formato simples que remontam a panelas relativamente fechadas, pratos e tigelas abertas. O tratamento de superfície é predominantemente alisado, com presença de decorações como digitado, corrugado, ungulado, ponteado, roletado, engobado e com impressão de cestaria. O antiplástico é comumente areia grossa ou mediana (areião); e a queima, indicada, sobretudo, pela coloração escura do núcleo, sugere o uso de fornos a céu aberto.

\section{A indústria lítica do sítio PT-02-Cerrito da Sotéia}

Matérias-primas: a indústria lítica identificada no Cerrito da Sotéia é composta por 501 materiais confeccionados em distintas matériasprimas, entre as quais, a mais representativa é o quartzo (364 peças, equivalente a 74\%), ocorrendo frequências menores de andesito (46 peças, equivalente a $9 \%$ ), granito (36 peças, equivalente a $6 \%$ ), basalto $A$ (21 peças, equivalente a $4 \%$ ), basalto $B$, (28 peças, equivalente a $6 \%$ ), riolito (5 peças, equivalente a $1 \%$ ), e quartzito ( 1 peça, menos de $1 \%$ ). No que se refere a variações de basalto, denominadas aqui de basalto "A" e basalto "B", o primeiro tipo de basalto apresenta coloração entre cinza escura e preta, possuindo textura afanítica ${ }^{9}$ homogênea, relativa, possivelmente, a porções próximas da superfície formada pelos derrames de falhas. O segundo tipo apresenta coloração próxima ao marrom escuro, com textura afanítica menos homogênea que 0 primeiro, podendo ser relativo a porções mais internas dos derrames de falhas.

O quartzito, que aparece na coleção com apenas um objeto, refere-se a uma rocha metamórfica em forma de seixo que foi utilizada para a produção de um instrumento com depressão semiesférica. Os

\footnotetext{
9 Termo utilizado especificamente para referir-se à granulometria fina de uma rocha ígnea vulcânica (PRESS et al., 2006).
}

Espaço Ameríndio, Porto Alegre, v. 7, n. 1, p. 10-36, jan./jun. 2013. 
ANDERSON M. GARCIA e RAFAEL G. MILHEIRA - Gestão de fontes de matéria-prima...

primeiros estudos sobre a indústria lítica podem ser vistos em Garcia (2010).

Quartzo: a indústria lítica sobre quartzo identificada no Cerrito da Sotéia foi embasada principalmente na técnica de lascamento bipolar (técnica de bigorna). Da totalidade de materiais apresentados, 196 peças derivam desta técnica (lascas, núcleos, nucleiformes e resíduos de lascamento), 70 lascas foram obtidas através da técnica unipolar (percussão direta), 87 peças podem ser referentes a ambas as técnicas (estilhas) e 11 peças são naturais, sem estigmas de lascamento que nos permitam definir a técnica utilizada (percutores, artefatos brutos, fragmentos naturais e lascas térmicas).

Entre os materiais em quartzo, percebeu-se uma quantidade significativa de córtex liso em $70 \%$ da totalidade da indústria, sugerindo que a aquisição deste material se deu com o recolhimento de seixos e blocos em corpos hídricos e suas planícies de inundação. A partir do quartzo foram confeccionados instrumentos suportados por lascas que possuem marcas de utilização, indicando atividades de corte, raspagem e perfuração. Os instrumentos de maior representatividade numérica são os furadores e furadores/raspadores, produzidos em lascas, sugerindo ter sido preparadas inicialmente por percussão bipolar controlada, feitas sobre núcleos de proporções próximas de $4 \mathrm{~cm}$ de comprimento, $2,5 \mathrm{~cm}$ de largura e $1,5 \mathrm{~cm}$ de espessura. Neste processo, eram removidas lascas laminares com morfologias já próximas à configuração final dos furadores, tendo, como último estágio, a remoção de micro lascas por pressão, tornando os instrumentos bifaciais, morfologicamente triangulares e pontiagudos.

Durante a análise, foi identificada na coleção uma série de núcleos que possibilitam uma relação com estes instrumentos. Embora não tenha sido possível a realização de remontagens, a hipótese torna-se plausível por meio de comparações entre os negativos dos furadores com os dos núcleos, onde ambos apresentam negativo de debitagem com formato triangular e de proporções semelhantes. 


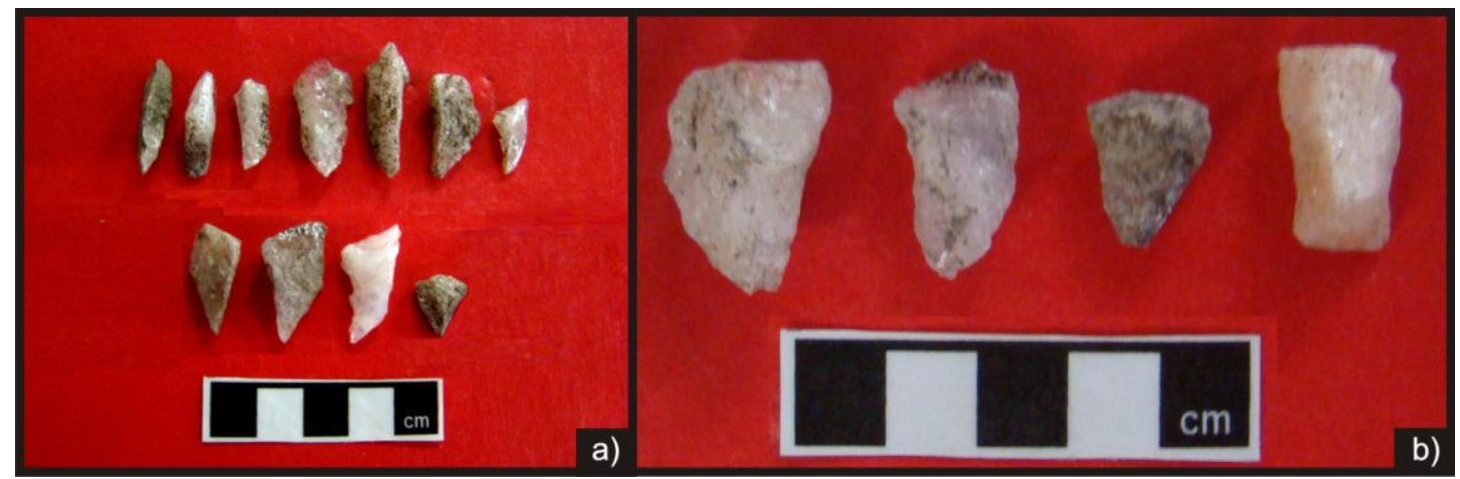

Figura 03: Relação entre os negativos dos furadores com os presentes nos núcleos.

Granito: os vestígios da indústria lítica sobre granito no Cerrito da Sotéia são escassos devido ao baixo número de objetos desta matériaprima, havendo apenas seis lascas no material analisado. Destas, quatro são bipolares e duas unipolares, estas últimas divididas em uma inicial ou cortical e outra secundária ou de redução. Quanto à ocorrência de núcleos, apenas três peças lascadas com técnica bipolar foram identificados, além de seis nucleiformes sem marcas de uso. Foram identificadas também duas peças com marcas diversificadas que remetem ao uso multifuncional, interpretadas como raspador/instrumento com depressão semiesférica/bigorna e instrumento com depressão semiesférica/polidor manual/bigorna.

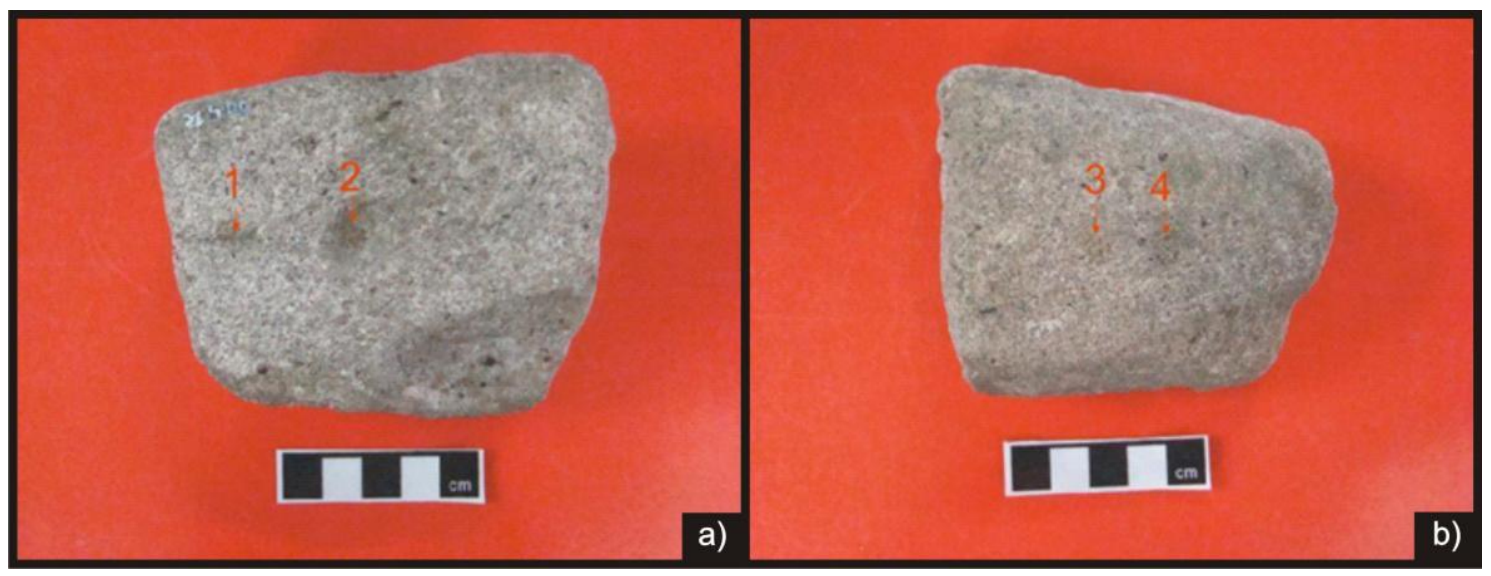

Figura 04: Instrumento com depressão semiesférica em granito. 
ANDERSON M. GARCIA e RAFAEL G. MILHEIRA - Gestão de fontes de matéria-prima...

$\mathrm{Na}$ figura 04 pode ser visto um exemplar deste tipo de instrumento produzido a partir de um bloco de granito, tendo em sua face ventral (a) uma fratura. Nas suas faces são observadas quatro depressões semiesféricas, duas em cada face, em que a primeira depressão tem $9 \times 3 \mathrm{~mm}$ (9 $\mathrm{mm}$ de diâmetro por $3 \mathrm{~mm}$ de profundidade), a segunda $13 \times 6 \mathrm{~mm}$, a terceira $12 \times 2 \mathrm{~mm}$ e a quarta $7 \times 2 \mathrm{~mm}$. Tais depressões foram provavelmente produzidas por picoteamento, seguido de polimento.

Rochas vulcânicas: Andesito, Basalto A, Basalto B, Riolito: O uso de rochas vulcânicas se deu através da coleta de seixos, pois o percentual de córtex liso nas rochas vulcânicas é de 56\%, havendo apenas uma peça com córtex rugoso na coleção (as demais peças não apresentam córtex). Existem entre estas matérias-primas três instrumentos brutos interpretados como mão de mó, bigorna e percutor e ou bigorna / polidor manual. Porém, a principal técnica utilizada no uso destas rochas foi o lascamento unipolar, visto que de cinquenta e oito lascas existentes na coleção, quarenta são unipolares e apenas dezoito são bipolares. Reforça tal hipótese o fato de haverem apenas três núcleos presentes e os mesmos apresentarem negativos de lascas unipolares. Percebe-se nestas rochas que a técnica bipolar foi desempenhada de maneira complementar, pois deste processo foram encontrados apenas oito instrumentos, quatro raspadores, uma faca, dois furadores e um furador / raspador.

A partir da técnica unipolar foram manufaturados dezesseis instrumentos: uma faca, cinco raspadores e dez "pontas". As pontas (figura 05), além de serem os instrumentos numericamente mais frequentes na indústria, merecem atenção por tratar-se de uma categoria diferente das pontas de projéteis vinculadas à preensão na parte ativa de armas de arremesso, comumente descritas na literatura especializada (HILBERT, 1991). Esses instrumentos foram produzidos em lascas unipolares que apresentam o eixo latitudinal superior ao longitudinal (lascas largas), sendo frequente a existência de retoques bifaciais marginais em seus bordos, o que, além de moldar o objeto em sua parte ativa, cria em sua porção morfológica proximal uma área que sugere algum tipo de encabamento. A funcionalidade destes materiais 
ANDERSON M. GARCIA e RAFAEL G. MILHEIRA - Gestão de fontes de matéria-prima...

não está bem clara, sendo, possivelmente, associadas a atividades de perfuração, corte e raspagem.

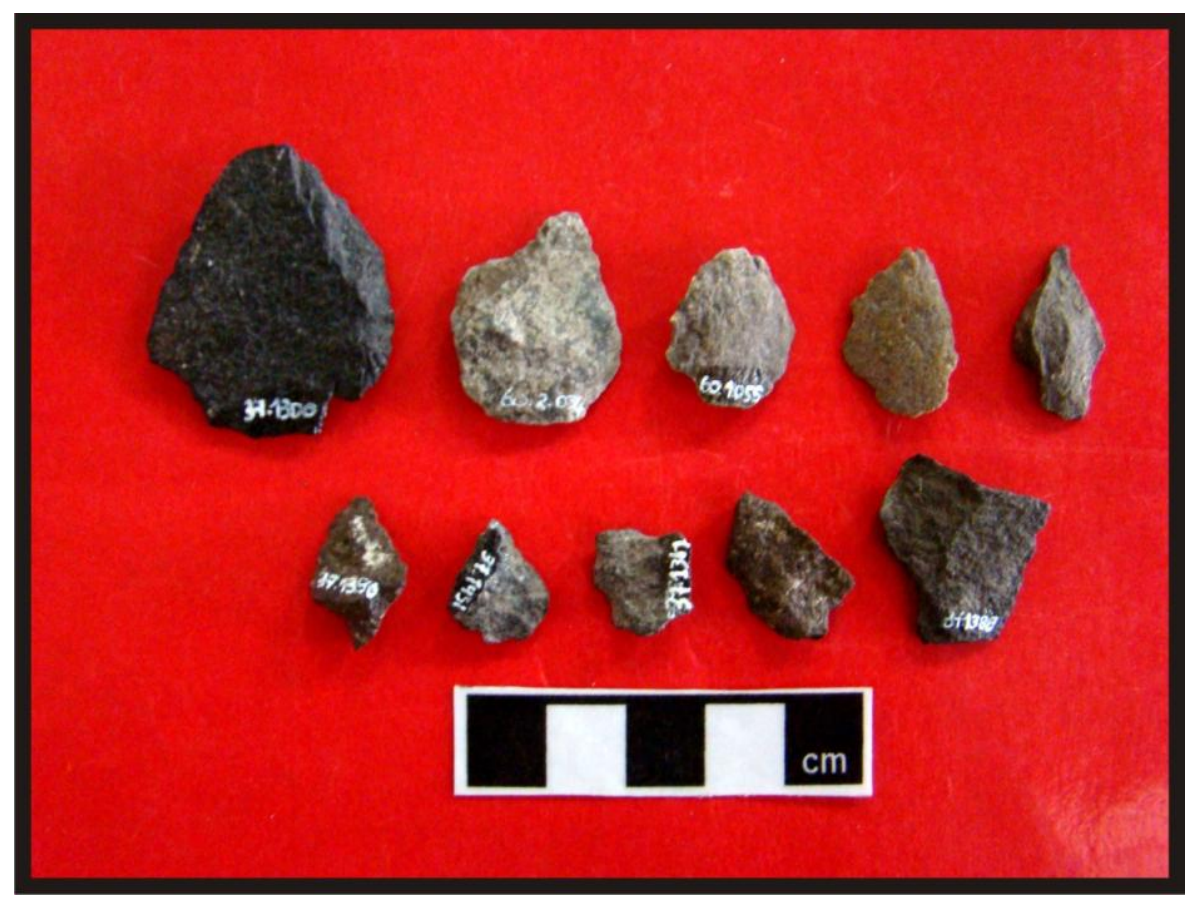

Figura 05: Instrumentos com retoques bifaciais marginais nos seus bordos.

\section{Análise em microscópio eletrônico de varredura (MEV)}

Ao longo da análise da indústria lítica do Cerrito da Sotéia, não foi possível classificar, apenas através de observação macroscópica, um tipo específico de rocha, sendo necessária a aplicação do método de microscopia eletrônica de varredura para inferir com propriedade a respeito da matéria-prima em questão. Esse método produz imagens por meio do mapeamento das intensidades dos elétrons emitidos pela superfície das amostras (DEDAVID, GOMES e MACHADO, 2007).

No processo de análise com MEV não existe ligação ótica entre os materiais analisados e a imagem resultante. Nesse procedimento a amostra, antes de ser submetida ao aparelho, é fixada com fita adesiva dupla face em um dispositivo de fixação amostral, para, em seguida, ser posta em uma câmara especial onde é recoberta por uma liga de metais nobres, nesta ocasião o $\mathrm{Au}$ (ouro). Este é o processo que torna o 
ANDERSON M. GARCIA e RAFAEL G. MILHEIRA - Gestão de fontes de matéria-prima...

material analisado condutor e que possibilita ao aparelho mapear as intensidades dos elétrons da amostra.

Com o material preparado adequadamente para o exercício da análise eletrônica, é então possível visualizá-lo em escala nanométrica, com o auxílio de um monitor que é acoplado ao sistema MEV. Além da imagem geral da amostra, o sistema ainda permite visualizar e analisar regiões particulares do material, possibilitando a leitura eletrônica de áreas específicas a partir de imagens e gráficos de cada porção escolhida. Desse modo, é possível verificar a composição química da amostra ou de porções dela por meios de feixes de elétrons que varrem o material no lugar desejado pelo pesquisador.

Para que a matéria-prima presente na indústria lítica pudesse ser analisada sob este método, foi retirado um fragmento de dois milímetros de uma lasca com uma pinça odontológica. Foi definido de modo arbitrário o centro da amostra como a região a ser analisada. Desta forma, primeiramente foi utilizada escala de $100 \mu \mathrm{m}$ para visualizar de modo geral a área escolhida; em seguida, a escala foi modificada para $5 \mu \mathrm{m}$, o que tornou possível a apreciação da matriz mineral da rocha. Com este exercício foi possível distinguir pelo menos três grupos de elementos morfologicamente distintos, que foram verificados com a expectativa de caracterizar os grupos minerais e inferir sobre a natureza de sua matéria-prima (figura 06-a).

A leitura da energia dispersiva de raio-X (EDX) da primeira subárea analisada (ampliada do original em 5.000 x), indicou uma quantidade significativa dos elementos $\mathrm{Fe}, \mathrm{Na}, \mathrm{Si}, \mathrm{Al}$ e $\mathrm{Mg}$ no mineral averiguado, além de um pico elevado de "Au". Porém, este último elemento é descartado da análise dos dados por tratar-se da substância utilizada no processo de metalização da amostra (figura 06-b). A ocorrência dos demais elementos na composição da amostra indica ser um mineral do grupo dos piroxênios. Esse grupo é da classe dos silicatos arranjados quimicamente em cadeias simples, um exemplo destes minerais é a enstatita (PRESS et al., 2006).

A segunda leitura por EDX, geradora de uma imagem ampliada em $10.000 \times$ do original (figura 06-c), apresentou uma forte presença dos elementos $\mathrm{Ca}, \mathrm{Na}, \mathrm{Si}, \mathrm{Al}$ e $\mathrm{Mg}$ no mineral varrido pelo feixe de elétrons. Somadas as características morfológicas deste mineral à presença dos 
elementos já citados, indica que o mineral evidenciado na amostra seja um plagioclásio, fazendo parte do grupo dos feldspatos que possui coloração esbranquiçada e sendo rico em Al e Ca (PRESS et al., 2006).

O terceiro EDX da amostra, desta vez com imagem resultante ampliada em $7.000 \times$ do original (figura 06-d), apontou a presença dos elementos Ca, Si e Al. Essa composição química, somada à morfologia do mineral averiguado pela análise eletrônica, sugere que a substância seja um mineral de gênese secundária da rocha, ou seja, um mineral originado devido à ação do intemperismo, oxidando a rocha e formando novos minerais durante este processo.

Por meio de uma visão reflexiva destes dados, percebe-se que os primeiros (piroxênio e plagioclásio) são minerais primários, relativos ao estágio de formação da rocha; e já o último, secundário, é derivado do intemperismo da matéria-prima.

Essa análise, aliada ao exercício da identificação das matériasprimas líticas, não pôde ser capaz de apontar com precisão o tipo de rocha analisado. No entanto, o MEV foi capaz de apontar dados químicos de elementos presentes na amostra, que, por sua vez, possibilitaram inferências sobre os minerais da rocha. Sendo assim, a partir dos minerais identificados (piroxênio, plagioclásio e mineral de gênese secundária) e da presença dos fenocristais ${ }^{10}$ de plagioclásio (que podem ser percebidos macroscopicamente), sugere-se que a amostra seja uma rocha do tipo andesito.

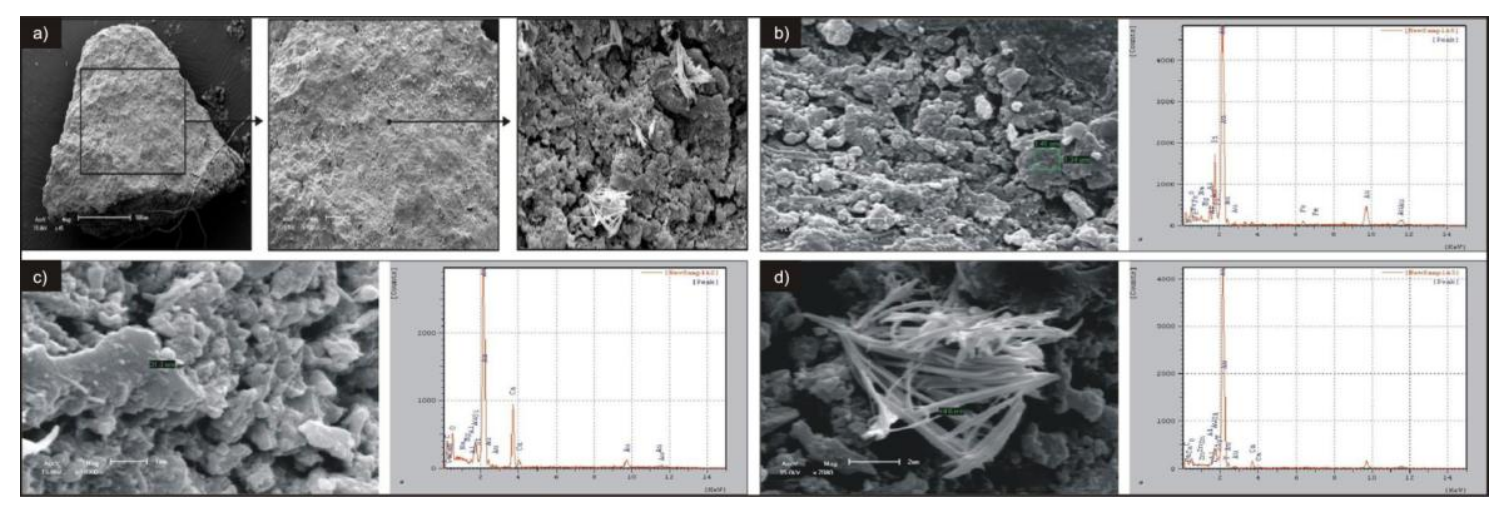

Figura 06: Análise em microscópio eletrônico de varredura (MEV).

\footnotetext{
${ }^{10}$ Cristais que se destacam devido ao seu tamanho e cor em meio a matriz fina de uma rocha vulcânica.
} 
Este tipo de inferência poderia ser ainda mais precisa se mais testes fossem feitos com um número maior de materiais arqueológicos comparados a diferentes fontes litológicas regionais e análises petrográficas (GALVÃO, 2010; POUPEAU et al., 2010). No entanto, existe um "rol" muito grande de fontes que distam em seus afloramentos originais mais de $200 \mathrm{~km}$ do sítio arqueológico, dificultando a identificação das mesmas.

\section{Mapeamento das fontes de matéria-prima}

Para identificar as possíveis fontes litológicas exploradas pelos ocupantes do Cerrito da Sotéia, buscou-se localizar, aleatoriamente, áreas possíveis para aquisição de matérias-primas líticas mais próximas ao sítio. Partimos à localização aleatória, num primeiro momento, em virtude da carência de estudos geológicos e litológicos específicos da região litorânea. Os poucos trabalhos que versam sobre a geologia local são bastante generalistas e reforçam ou sintetizam pesquisas antigas, como os dados apresentados no Radam Brasil (1986). Logo, com o intuito de ter uma visão geral das unidades geológicas com presença destas matérias-primas, primeiro se consultou o mapa geológico do Estado do Rio Grande do Sul (CARRARO et al., 1974) e de Pelotas (MARTH, KOESTER e ARNDT, 2008), e, em sequência, foi-se a campo para a realizar um mapeamento específico das fontes litológicas.

Concebendo o Escudo Sul-Rio-Grandense como uma província Pré-Cambriana composta predominantemente por rochas ígneas plutônicas e com incidências menores de outras naturezas (CHEMALE JÚNIOR, 2000), analisaram-se em campo as possibilidades de fragmentos deste tipo de rocha ser transportado através de corpos hídricos até terrenos com cotas topográficas mais baixas. No Arroio Corrientes, corpo hídrico com nascente no Escudo Sul-Rio-Grandense mais próximo ao Cerrito da Sotéia, foi realizada uma saída de campo em um ponto da divisa entre Pelotas e Turuçu. Nesta atividade foi possível localizar pequenos seixos de quartzo que coincidem com as dimensões dos seixos utilizados na indústria lítica do sítio. Também foram identificados clastos de granito, em que o maior deles apresentava as 
dimensões de $9,5 \mathrm{~cm}$ de comprimento, $6,7 \mathrm{~cm}$ de largura e $2,6 \mathrm{~cm}$ de espessura.

Essa localização pode indicar que, em épocas de grande fluxo no arroio Corrientes, materiais rochosos com as dimensões encontradas, e ainda superiores, poderiam ser deslocados e depositados em pacotes sedimentares como o localizado em campo. Isto sugere que tal corpo hídrico, assim como outros mais afastados, poderia ter servido como uma fonte de aquisição destas matérias-primas líticas. Seixos de quartzito não foram encontrados nesta atividade, mas por haver no Escudo Sul-rio-grandense esta rocha associada ao granito, pensa-se que, eventualmente, o Arroio Corrientes pudesse também ser responsável pelo transporte de seixos desta rocha.

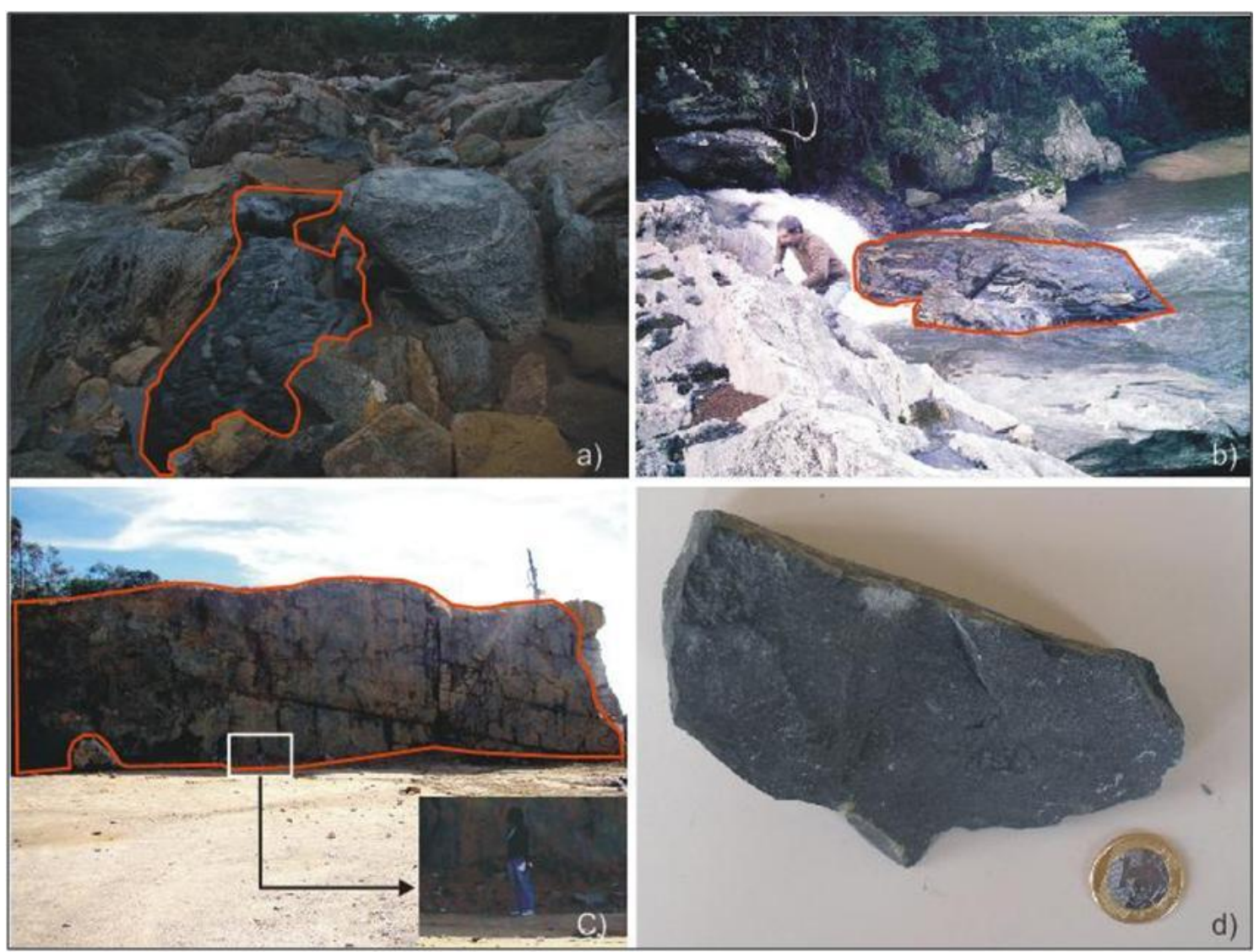

Figura 07: Diferentes locais com presença de basalto em forma de dique no município de Pelotas. Arroio Kaster (a); Cachoeira do Imigrante (b); Pedreira Pelotense (c); amostra de basalto de coloração preta/cinza da Pedreira Pelotense (d). 
ANDERSON M. GARCIA e RAFAEL G. MILHEIRA - Gestão de fontes de matéria-prima...

As demais matérias-primas (andesito, basalto e riolito) são rochas ígneas vulcânicas e possuem origem geológica conhecida relativa à Formação Serra Geral, no Planalto Sul-rio-grandense (ROISENBERG \& VIERO, 2000). No entanto, embora não haja referências na literatura especializada, foram encontrados no interior de Pelotas três pontos de ocorrência de uma variedade de basalto de coloração entre cinza escura e preta em falhas de rochas plutônicas graníticas. Este basalto é semelhante ao basalto $\mathrm{A}$ identificado na indústria lítica do Cerrito da Sotéia (figura 07).

Quanto ao andesito, riolito e também ao basalto de coloração próxima ao marrom escuro'1, não foi possível verificar em campo ocorrências destas nas proximidades do município de Pelotas. Assim, pôde-se apenas apontar afloramentos fixos destas matérias-primas no mapa geológico do Rio Grande do Sul. Essas rochas têm suas fontes mais próximas relativas ao Cerrito da Sotéia em municípios como São Leopoldo (andesito) e Caçapava do Sul (riolito). Embora se trate de uma variedade diferente, trazemos também a localização de uma outra formação de basalto existente em Jaguarão.

\section{Gestão das fontes de matéria-prima}

Através da análise de córtex das rochas identificadas na coleção pode-se compreender que o aprovisionamento de matéria-prima é bastante variado. A análise da indústria lítica indicou que os ocupantes do Cerrito da Sotéia utilizaram quartzo, granito e uma série de rochas ígneas vulcânicas como suporte à manufatura de seus instrumentos, tendo sido a maior parte destes materiais adquiridos em corpos hídricos ou planícies de inundação. Esta interpretação se dá em função da frequência de $90 \%$ de peças com córtex liso (arredondado ou levemente anguloso) entre o montante com córtex em geral, indicando que as massas iniciais utilizadas estiveram expostas em ambientes hídricos por longos períodos. Neste sentido, a ampla frequência de seixos indica que

\footnotetext{
${ }^{11}$ Como mencionado anteriormente, existe a possibilidade deste basalto estar relacionado a pacotes litológicos mais profundos. Talvez por este motivo não tenha sido identificada com clareza, na literatura geológica, afloramentos que possibilitem uma associação direta com esta variedade de basalto.
}

Espaço Ameríndio, Porto Alegre, v. 7, n. 1, p. 10-36, jan./jun. 2013. 
corpos hídricos com potência suficiente para o transporte de materiais pesados estavam sendo mapeados pelos grupos construtores de Cerritos, servindo de fontes de captação de matéria-prima lítica. 0 quartzo e o granito, além de aflorarem em grande parte do Escudo Sulrio-grandense, puderam ser encontrados em forma de seixos e clastos no Arroio Corrientes a um raio de $24 \mathrm{~km}$, a partir do Cerrito da Sotéia.

Por outro lado, há peças em quartzo e granito que foram retiradas de blocos das áreas altas da serra do Sudeste, cuja matriz geológica é o Escudo Sul-Rio-Grandense, sugerindo que esta região também estava sendo sistematicamente explorada. Ocorrem nas proximidades do Cerrito da Sotéia intrusões de basalto a um raio de $49 \mathrm{~km}$ no Arroio Kaster. A $49 \mathrm{~km}$ na Cachoeira do Imigrante e a $43 \mathrm{~km}$ há um dique com volume em superfície de mais $2000 \mathrm{~m}^{3}$, em uma área hoje exposta e explorada comercialmente.

Com relação às demais fontes de matéria-prima, o mapa geológico do Estado do Rio Grande do Sul aponta que há uma fonte de basalto distanciada a cerca de $160 \mathrm{~km}$ de raio, a partir do Cerrito da Sotéia; uma fonte de riolito a $155 \mathrm{~km}$, e de andesito a $220 \mathrm{~km}$.

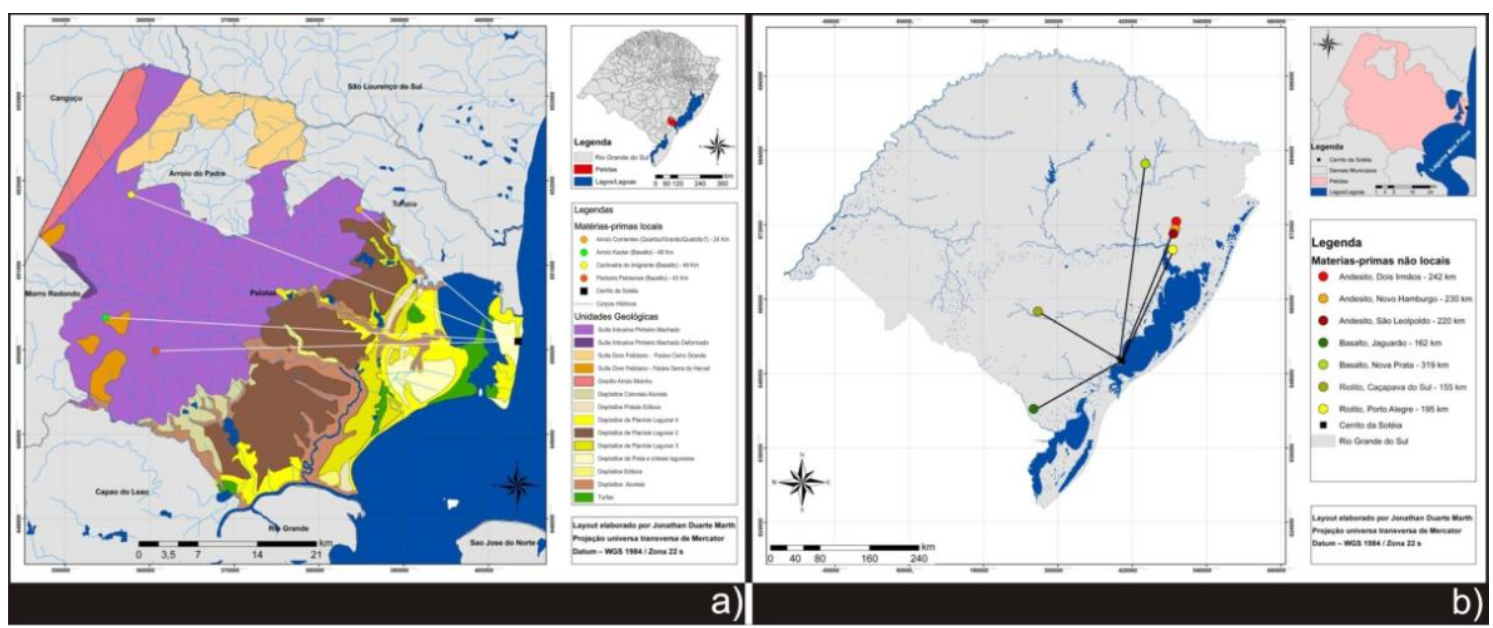

Figura 08: Mapa geológico de Pelotas com destaque para possíveis zonas de atividade econômica próximas ao Cerrito da Sotéia (a). Mapa ilustrativo do Rio Grande do Sul com destaque para possíveis zonas de atividade econômica distantes do Cerrito da Sotéia. Layout elaborado Jonathan Duarte Marth.

Com base nessas informações, foram gerados dois mapas georreferenciados que ilustram as áreas de ocorrência das possíveis 
ANDERSON M. GARCIA e RAFAEL G. MILHEIRA - Gestão de fontes de matéria-prima...

fontes litológicas e as distâncias das mesmas com relação ao sítio arqueológico estudado (figura 08). O primeiro mapa foi produzido para ilustrar a localização das fontes litológicas encontradas em campo (com exceção ao quartzito), os quais ocorrem entre 24 e $50 \mathrm{~km}$ do Cerrito da Sotéia. O segundo mapa foi produzido para ilustrar as fontes litológicas que constam na cartografia geológica, a distâncias entre 50 e 220 km, em linha reta a partir do Cerrito da Sotéia.

A exploração de fontes de matéria-prima lítica a distâncias que podem variar de 24 a $220 \mathrm{~km}$ incitam à discussão sobre o sistema de mobilidade dos grupos construtores de cerritos e a zonas de captação de recursos. Binford (1983), em seu clássico estudo sobre a Arqueologia do Lugar, propõe que grupos de caçadores-coletores costumam criar padrões de mobilidade que atendem a demandas particulares do sistema comportamental humano. Esse padrão de mobilidade é organizado em raios de ação econômica ou zonas de atividades econômicas (zones of economic activity), que variam em distâncias a partir do acampamento central, cujas medidas são condicionadas pelo transporte, custo de trabalho para exploração dos recursos das áreas de captação e qualidade dos recursos. Observa-se que o autor não se baseava apenas no aprovisionamento de recursos líticos para pensar o raio de ação dos grupos caçadores-coletores, visto que a economia destes grupos envolve recursos alimentícios e outros recursos orgânicos e inorgânicos que condicionam o padrão de mobilidade e o raio de ação para captação dos recursos. Porém, em nosso caso, trata-se de um primeiro exercício, e futuramente buscaremos integrar os dados sobre o aprovisionamento de matérias-primas líticas aos demais recursos orgânicos e inorgânicos que ocorrem nos Cerritos da região em estudo.

Considerando válido este primeiro exercício, pode-se pensar que os cerriteiros adotaram estratégias de aprovisionamento de recursos líticos em uma ampla área, em zonas de atividades econômicas distintas.

1) Uma primeira zona econômica abrangeria um raio de aproximadamente 24 a $50 \mathrm{~km}$, em que seriam mapeados e frequentemente explorados os rios e córregos com alto potencial energético para transporte de seixos e clastos, onde se encontram estas matérias-primas em "cascalheiras" localizadas em cotas baixas dos 
ANDERSON M. GARCIA e RAFAEL G. MILHEIRA - Gestão de fontes de matéria-prima...

leitos destes corpos hídricos. Além disso, dentro desse raio de captação de recursos, estaria a região da serra do Sudeste, onde blocos de quartzo e granito, assim como pontuais diques de basalto, estariam à disposição dos grupos construtores de Cerritos. Este raio de captação poderia ser explorado rotineiramente com um esforço de transporte e custo de trabalho relativamente baixos, visto que os cerriteiros utilizavam-se de embarcações como meios de transporte, o que permitiria otimizar a captação dos recursos. O trabalho de Carle, Carle e Carle (2002) subsidia a hipótese de que os grupos cerriteiros se utilizavam de embarcações quotidianamente. Esses autores identificaram traços de estresse músculo esquelético ${ }^{12}$ nos vestígios ósseos de dois indivíduos sepultados, provenientes do Cerrito RS-LS85, localizado no município de Rio Grande-RS. Os esqueletos apresentavam patologias como traumatismos na cabeça do cúbito (afetando o cotovelo), achatamento na tíbia (indicativo de agachamento por longos períodos) e clavícula com entesopatia e artrose. Tal diagnóstico levou os pesquisadores a interpretar estes sintomas como consequências do ato de remar durante as atividades de pesca e de transporte, atividades estas relacionadas à economia e ao sistema de mobilidade dos grupos cerriteiros. Além deste estudo de antropologia física, Basile-Becker (2002) e López Mazz e Bracco (2010) também fazem referências sobre a existência de transportes embarcados ao trazer um relato de Pero Lopes de Sousa (século XVI) sobre o uso de canoas pelos Charrua.

2) Uma segunda zona de atividades econômicas teria um raio de 50 a $220 \mathrm{~km}$, em que as amplas distâncias das fontes litológicas requerem uma estratégia mais sofisticada para aquisição das matériasprimas. Sobre a aquisição de riolito, as fontes desta matéria-prima mais próximas conhecidas estão relacionadas ao município de Caçapava do Sul-RS. Este município tem seu território banhado pelo Rio Camaquã, um dos cursos hídricos de maior extensão, competência e variedade litológica do Rio Grande do Sul. Esse rio foi interpretado por Rüthschlling (1987) como uma área de coleta dos seixos que

12 "O estudo envolvendo marcadores de estresse músculo esquelético (MEMs), tem como objetivo estabelecer padrões de atividades físicas e laborais, ao tentar reconstruir os grupos musculares mais solicitados e, consequentemente, os movimentos possíveis realizados por estes" (SCHERER, RODRIGUES-CARVALHO e SCHMITZ, 2006, p. 55).

Espaço Ameríndio, Porto Alegre, v. 7, n. 1, p. 10-36, jan./jun. 2013. 
ANDERSON M. GARCIA e RAFAEL G. MILHEIRA - Gestão de fontes de matéria-prima...

sustentaram as indústrias líticas existentes nos Cerritos por ela estudados na região do município de Camaquã-RS.

Posto isso, sugerimos que as estratégias de captação de recursos líticos operadas pelos construtores de cerritos estariam vinculadas à disponibilidade e proximidade das fontes, sejam elas em leitos de corpos hídricos ou em diques e afloramentos. Percebe-se que a frequência de uso do quartzo atinge um percentual de $74 \%$ da indústria lítica do Cerrito da Sotéia, enquanto as demais matérias-primas alcançam a frequência de apenas 26\%. Estes dados são indicativos, em nossa opinião, de que as fontes locais são preferidas para comporem a cadeia operatória, operando-se estratégias de aprovisionamento destes recursos com baixo custo.

Semelhante ao que ocorre no Cerrito da Sotéia, a indústria lítica dos cerritos do banhado do colégio, como demonstrado por Rüthschlling (1987), é baseada no uso de rochas vulcânicas (com grande presença de riolito) do leito do rio Camaquã, estando, por sua vez, num raio de captação de fácil acesso. No entanto, é comum encontrar matérias-primas alóctones compondo a indústria lítica dos Cerritos, pois, segundo Bracco, Puerto e Inda (2008), em muitos casos, o fator qualitativo das matérias-primas parece ter preponderado na decisão de quais fontes litológicas deveriam ser exploradas, ainda que as mesmas ocorressem fora da área de dispersão dos Cerritos. A exploração de matérias-primas alóctones e autóctones à área de dispersão dos Cerritos, inclusive, tem sido tratada pelos arqueólogos como um indicar de articulação entre os distintos ambientes litorâneos e interioranos, o que reforça a interpretação de que o padrão de mobilidade dos grupos cerriteiros configura-se como uma economia de "amplo espectro" que se manifesta com um baixo grau de especialização e alto grau de adaptabilidade às variações espaço-temporais de oferta dos recursos (BRACCO, PUERTO E INDA, 2008, p. 29).

Dessa maneira, propõe-se que o sistema de mobilidade dos grupos cerriteiros articulado entre distintos ambientes garante 0 aprovisionamento de diferentes tipos de matérias-primas líticas, coletadas em distintas fontes litológicas no Estado do Rio Grande do Sul. Não temos dados seguros ainda, mas não se pode descartar a possibilidade de troca de materiais líticos entre parcialidades do sistema 
ANDERSON M. GARCIA e RAFAEL G. MILHEIRA - Gestão de fontes de matéria-prima...

de assentamento litorâneo dos grupos construtores de cerritos. Caberá a pesquisas futuras procurar os indicadores de trocas de matériasprimas líticas entre parcialidades do sistema de assentamento regional, trazendo à luz discussões mais precisas. Em se tratando de sistema de trocas de materiais, caso elas venham a se confirmar, poder-se-ia pensar em redes que permitiriam aos indivíduos otimizar a aquisição de matérias-primas líticas com um baixo custo energético.

\section{Conclusão}

Buscou-se com este trabalho uma reflexão inicial sobre o aprovisionamento e gestão de matérias-primas líticas exploradas pelos grupos construtores de Cerritos da porção Sudoeste da Laguna dos Patos, através de um estudo de caso com base na indústria lítica do sítio "PT-02-Cerrito da Sotéia". As cascalheiras, diques e afloramentos de rochas que possivelmente foram utilizadas como fontes de matériaprima para confecção de instrumentos lascados e polidos de uso quotidiano foram mapeadas em diferentes escalas ao longo dos séculos em que estes grupos habitaram a costa litorânea da Laguna dos Patos. $O$ mapeamento e o reconhecimento destas fontes de matéria-prima lítica permitem pensar que o território de domínio dos construtores de Cerritos abrangia zonas de atividades econômicas que variam de 24 a $220 \mathrm{~km}$. Haveria uma zona de ação oscilando num raio de 24 a $50 \mathrm{~km}$ que seria explorada através de uma estratégia logisticamente simples; e, por outro lado, uma zona oscilando num raio de 50 a $220 \mathrm{~km}$ que requer uma logística e planejamento mais sofisticado. Esta segunda zona, pela sua amplitude, seria explorada por estratégias de mobilidade e, talvez, redes de troca de materiais entre parcialidades do sistema de assentamento dos grupos construtores de Cerritos. O amplo sistema de mobilidade já mencionado em diversos trabalhos como Schmitz (1976), Rüthschlling (1987), López Mazz e Bracco (2010) garantiria aos grupos cerriteiros a aquisição e circulação de matérias-primas líticas, coletadas em distintas fontes litológicas no espaço pampiano.

Futuramente pretende-se continuar a discussão sobre o tema. É necessário, por exemplo, testar os conceitos de zonas de atividades 
ANDERSON M. GARCIA e RAFAEL G. MILHEIRA - Gestão de fontes de matéria-prima...

econômicas, no que se refere à amplitude do raio de captação de recursos e integração a outros recursos orgânicos e inorgânicos. É importante também que sejam feitos estudos detalhados das indústrias líticas provenientes de diferentes Cerritos da porção meridional da laguna dos Patos, identificando-se as fontes litológicas e suas distâncias com relação aos sítios arqueológicos. Da mesma forma, estudos de petrografia comparando amostras de rochas das distintas fontes litológicas com os materiais que compõem as indústrias líticas dos Cerritos poderiam ser de ampla contribuição para a precisão do uso das fontes. Com este trabalho apresentamos um exercício que permite inferir sobre as diferentes escalas de exploração dos recursos litológicos; porém, outros estudos de caso e estudos comparativos permitirão avançar nesta discussão, trazendo à luz novas considerações que colaborem para o entendimento da sociedade dos grupos construtores de Cerritos e a gestão das matérias-primas que compõem a indústria lítica.

\section{Referências bibliográficas}

BASILE-BECKER, Ítala Irene. O que sobrou dos índios pré-históricos do Rio Grande do Sul. In: KERN, Arno Alvarez (Org.). Arqueologia pré-histórica do Rio Grande do Sul. Porto Alegre: Mercado Aberto, 1992. p. 331-356.

Os Índios Charruas e Minuanos na Antiga Banda Oriental do Uruguai. São Leopoldo: Ed.Unisinos, 2002.

BELLETTI, Jaqueline da Silva. Uns caquinhos num montão de terra: o que fazer com eles? Discussões sobre cerâmica em cerritos no sudoeste da laguna dos Patos. 2010. 202 f. Monografia (Bacharelado em História) - Universidade Federal de Pelotas, [2010].

BINFORD, Lewis R. Organization and formation process: looking at curated technologies. Working at Archaeology, Nova York, v. 35, n. 3, p. 255-273, 1983.

BONOMO, Mariano; POLITIS, Gustavo; GIANOTTI. Camila García. Montículos, jerarquía social y horticultura en las sociedades indígenas del delta del Río Paraná (Argentina). Latin American Antiquity, Washington, v. 22, n. 3, p. 297-333, 2011. 
ANDERSON M. GARCIA e RAFAEL G. MILHEIRA - Gestão de fontes de matéria-prima...

BRACCO, Roberto; PUERTO, Laura del; INDA, Hugo. Prehistoria y Arqueología de la Cuenca de Laguna Merín. In: LOPONTE, Daniel; ACOSTA, Alejandro (Org.). Entre la Tierra y el Agua: Arqueología de Humedales de Sudamérica. Buenos Aires: AINA, 2008. p. 1-60.

CARLE, Ana Cristina Baptista; CARLE, Cláudio Baptista; CARLE, Mirian Baptista. Relatório descritivo de dois esqueletos de indivíduos encontrados em trabalho arqueológico no Capão Seco, Rio Grande-RS, pelo pesquisador Pedro Augusto Mentz-Ribeiro. Trabalho Acadêmico. Porto Alegre: Pontifícia Universidade Católica do Rio Grande do Sul, 2002.

CARRARO, Clóvis C. et al. Mapa geológico do Estado do Rio Grande do Sul. Porto Alegre: Ed.UFRGS, 1974.

CHEMALE JÚNIOR, Farid. Evolução geológica do Escudo Sul-Rio-Grandense. In: HOLZ, Michael; DE ROS, Luiz Fernando (Org.). Geologia do Rio Grande do Sul. Porto Alegre: CIGO/UFRGS, 2000. p. 13-52.

COPÉ, Silvia M. A ocupação pré-colonial do sul e sudeste do Rio Grande do Sul. In: KERN, Arno Alvarez (Org.). Arqueologia pré-histórica do Rio Grande do Sul. Porto Alegre: Mercado Aberto, 1992. p.191-220.

DEDAVID, Berenice Anina; GOMES, Carmem Isse; MACHADO, Giovanna. Microscopia Eletrônica de Varredura: aplicações e preparações de amostras, materiais poliméricos, metálicos e semicondutores. Porto Alegre: Ed.PUCRS, 2007.

GALVÃO, Tiago Dutra. Caracterização química elementar e identificação de fontes de obsidianas utilizando fluorescência de raios $x$ com equipamento portátil (PXRF). 2010, 197 f. Dissertação (Mestrado em Física) - Universidade Estadual de Londrina, [2010].

GARCIA, Anderson Marques. As Cadeias Operatórias de uma indústria tecnológica lítica: sítio arqueológico PT-02 (Cerrito da Sotéia), Pelotas-RS. 2010. $124 \mathrm{f}$. Monografia (Licenciatura em Geografia) - Universidade Federal de Pelotas, [2010].

HILBERT, Klaus. Aspectos de la arqueología en el Uruguay. Von Zabern: Mainz am Rhein, 1991.

IRIARTE, José A. Organización de la tecnología lítica en la Costa Atlántica de los humedales de Rocha. In: DURÁN COIROLO, Alícia; BRACCO BOKSAR, Roberto (Org.). Arqueología de las Tierras Bajas. Montevidéu: Ministerio de Educación y Cultura, 2000. p. 71-82.

LÓPEZ MAZZ, José M. Investigación arqueológica y usos del pasado: tierras bajas del Este de Uruguay. TAPA (traballos en arqueoloxia da paisaxe), Santiago de Compostela, n. 19, p. 63-73, 2000. 
LÓPEZ MAZZ, José M.; BRACCO, Diego. Minuanos: apuntes y notas para la historia y la arqueología del territorio Guenoa-Minuan (indígenas de Uruguay, Argentina y Brasil). Montevidéu: Linardi y Risso, 2010.

LÓPEZ MAZZ, José M.; GIANOTTI. Camila G. Construcción de espacios ceremoniales públicos entre los pobladores prehistóricos de las tierras bajas de Uruguay: el estudio de la organización espacial en la localidad arqueológica Rincón de los Indios. Revista da SAB, São Paulo, n. 11, p. 87-106, 1998.

LOUREIRO, André Garcia. Sítio PT-02-Sotéia: análise dos processos formativos de um Cerrito na região Sudoeste da Laguna dos Patos/RS. 2008. 89 f. Dissertação (Mestrado em História) - Universidade de São Paulo, [2008].

MARTH, Jonathan Duarte; KOESTER, Edinei; ARNDT, Arthur Lacerda. Mapa geológico-geomorfológico do município de Pelotas, RS. XVII Congresso de Iniciação Científica e X Encontro de Pós-Graduação. Pelotas, UFPel. 17, 2008. p. 1-5.

MILHEIRA, Rafael Guedes. Território e estratégia de assentamento Guarani na Planície Sudoeste da Laguna dos Patos e Serra do Sudeste - RS. 2008. 224 f. Dissertação (Mestrado em Arqueologia) - Universidade de São Paulo, [2008].

MÜHLEN, Cristiano Von et al. Mapeamento arqueológico de Pelotas e região: os Cerritos em foco. XX Congresso de Iniciação Científica. Pelotas, UFPel. 20, 2011. p. $1-4$.

NAUE, Guilherme. Dados sobre o estudo de cerritos na área meridional da Lagoa dos Patos, Rio Grande, RS. Veritas, Porto Alegre, n. 71/73, p. 1-24, 1973.

PEREIRA, Cláudio. Minuanos/Guenoas: os Cerritos da bacia da Lagoa Mirim e as origens de uma nação pampiana. Porto Alegre: Fundação Cultural Gaúcha - MTG, 2008.

PINTOS BLANCO, Sebastián. Túmulos, caciques y otras historias: Cazadores recolectores complejos en la cuenca de la Laguna de Castillos, Uruguay. Complutum, Madrid, v. 10, p. 213-226, 1999.

POUPEAU, Gérard et al. The use of SEM-EDS, PIXE and EDXRF for obsidian provenance studies in the Near East: a case study from Neolithic Çatalhöyük (central Anatolia). Journal of Archaeological Science, Amsterdam, v. 37, p. 2705-2720, 2010.

PRESS, Frank et al. Para entender a Terra. Porto Alegre: Bookman, 2006.

RADAM BRASIL. Levantamento de recursos naturais da Secretaria do Planejamento da Presidência da República. Brasília: Instituto Brasileiro de Geografia e Estatística, 1986. 
ANDERSON M. GARCIA e RAFAEL G. MILHEIRA - Gestão de fontes de matéria-prima...

ROISENBERG, Ari; VIERO, Antonio Pedro. O vulcanismo mesozoico da Bacia do Paraná no Rio Grande do Sul. In: HOLZ, Michael; DE ROS, Fernando (Org.). Geologia do Rio Grande do Sul. Porto Alegre: CIGO/UFRGS, 2000. p. 355-374.

ROSA, Mário. Geografia de Pelotas. Pelotas: Ed.UFPel, 1985.

RÜTHSCHILLING, Ana Luisa. Uma nova abordagem sobre o material lítico do sítio RS-CA-14, Capão Grande-RS. Documentos, São Leopoldo, v. 1, p. 27- 49, 1987.

Pesquisas Arqueológicas no Baixo Rio Camaquã. Documentos, São Leopoldo, v. 3, p. 7-106, 1989.

SCHERER, Luciane Zanenga; RODRIGUES-CARVALHO, Cláudia; SCHMITZ, Pedro Ignácio. Marcadores de estresse músculo-esquelético em populações pescadoras, caçadoras e coletoras do litoral central de Santa Catarina. Pesquisas, antropologia, São Leopoldo, v. 63, p. 55-80, 2006.

SCHMITZ, Pedro Ignácio. Sítios de pesca lacustre em Rio Grande, RS, Brasil. 1976. 237 f. Tese (Livre Docência) - Universidade do Vale do Rio dos Sinos, [1976].

SCHMITZ, Pedro Ignácio; NAUE, Guilherme; BASILE-BECKER, Ítala Irene. Os aterros dos campos do sul: a Tradição Vieira. In: KERN, Arno Alvarez (Org.). Arqueologia pré-histórica do Rio Grande do Sul. Porto Alegre: Mercado Aberto, 1992. p. 221-250.

ULGUIM, Priscilla Ferreira. Zooarqueologia e o estudo dos grupos contrutores de cerritos: um estudo de caso no litoral da laguna dos Patos-RS, sítio PT-02 cerrito da sotéia. 2010. 200 f. Monografia (Bacharelado em História) - Universidade Federal de Pelotas, [2010].

VILLAGRÁN, Ximena Suárez. Emergencia de monumentalidad en el Este uruguayo. Montevidéu: Universidad de la Republica, 2005.

VILLWOCK, Jorge Alberto; TOMAZELLI, Luiz José. Geologia do Rio Grande do Sul. Notas Técnicas do CECO-IG-UFRGS, Porto Alegre, v. 8, p.1-45, 1995.

Espaço Ameríndio, Porto Alegre, v. 7, n. 1, p. 10-36, jan./jun. 2013. 